\title{
Perbandingan Perilaku Jajan, Konsumsi Makanan Cepat Saji serta Tidur Siang berdasarkan Status Obesitas pada Remaja
}

\section{The Comparison of Snacking, Fast Food Consumption and Napping Habbit Based on Obesity Status Among Adolescent}

\author{
Retno Mardhiati,Arif Setiawan \\ Program Studi Kesehatan Masyarakat Fakultas Ilmu-Ilmu Kesehatan, \\ Universitas Muhammadiyah Prof. Dr.Hamka Jakarta
}

\begin{abstract}
ABSTRAK
Dampak jangka pendek akan menurunkan produktifitas dan menurunkan rasa percaya diri remaja, sedangkan dampak jangka panjang akan menimbulkan penyakit degeneratif. Tujuan penelitian ini adalah membandingkan perilaku remaja obesitas dan bukan obesitas berdasarkan kebiasaan konsumsi makanan cept saji dan perilaku jajan, menonton televisi serta kebiasaan tidur siang.Desain penelitian ini adalah Cross Sectional dengan jumlah sampel 120 siswa/i pada salah satu SMA di Jakarta tahun 2017. Teknik sampling menggunakan sampling jenuh. Jenis data primer yang dikumpulkan dengan wawancara dan pengukuran berat badan dan tinggi badan. Instrumen yang digunakan adalah kuesioner. Analisis data dilakukan dengan analisis perbandingan proporsi. Terdapat perbedaan proporsi dimana remaja obesitas lebih banyak yang memiliki kebiasaan konsumsi makanan cepat saji, jajan di sekolah dan menonton televisi lebih dari 4 jam per hari daripada remaja non-obesitas. Diperlukan upaya edukasi dalam bentuk penyuluhan dan konseling pada remaja obesitas sangat membantu memotivasi remaja obesitas untuk merubah perilaku makan dan aktifitasnya.
\end{abstract}

Kata kunci : obesitas, remaja, pola makan, asupan energi, asupan lemak

\section{ABSTRACT}

Obesity, in the short period, has an impact for adolescent namelydecreasing productivity and self-confidence. While in long period, it may cause an occurence of degenerative diseases. The aim of this study is comparing the behavior of obese and non-obese adolescents based on their fast food consumption, snacking, watching television and napping habit. This research is a cross sectional designed study with sample number was 120 students in one High school in Jakarta as the sample. Saturated sampling technique was used in selecting the sample. Data was collected by interview using questionnaire and measuring students' body weight. The data analysis was using proportional comparison test.There was a difference proportion in which adolescent with obesity more has a habit on consuming fast food, snacking while in the school and watching television more than 4 hours/day compared by adolescent with non-obesity. There is a need on educating and counseling for adolescet with obesity in order to motivate them to change their habit in eating and daily activity.

Keyword : obesity, adolescents, eating pattern, energy intake, fat intake

\section{PENDAHULUAN}

Kelebihan berat badan dan obesitas didefinisikan sebagai akumulasi lemak abnormal atau berlebihan yang menjadi risiko terhadap kesehatan (Childhood, Tasked, Who, Growth, \& Controlling, 2018). Ukuran obesitas adalah Indeks Massa Tubuh (IMT), yaitu berat badan seseorang (dalam kilogram) dibagi dengan kuadrat tinggi badannya (dalam meter). Seseorang dengan BMI 30 atau lebih umumnya dianggap obesitas. Seseorang dengan BMI sama dengan atau lebih dari 25 dianggap kelebihan berat badan (overweight) (Childhood et al., 2018).

Obesitas atau kegemukan terjadi pada saat badan menjadi gemuk (obese) yang disebabkan penumpukan adipose (adipocytes: jaringan lemak khusus yang disimpan tubuh) secara berlebihan. Obesitas pada remaja menjadi salah satu masalah 
kesehatan remaja (Salam, 2010). Obesitas akan menjadi masalah kesehatan serius yang dapat mengakibatkan masalah emosional dan sosial (Hendra, dkk, 2016) menyatakan. Ketika seorang berat badannya memiliki tambahan $10 \%$ sampai dengan $20 \%$ berat badan normal dikatakan overweight, jika sudah bertambah lebih dari $20 \%$ berat badan normal dikatakan obesitas.

Saatini, terlihat ada peningkatan prevalensi obesitas pada anak di dunia, dan diprediksi tahun 2020 mencapai 9,1\% (de Onis et al. 2010). Prevalensi obesitas pada anak rentang usia 5-15 tahun sebesar 8,3\% di Indonesia (Sartika, 2011). Sementaraitu, prevalensi obesitas pada remaja di kabupaten Minahasa adalah sebesar 26,33\% yang terdiri dari $4,30 \%$ remaja perempuan dan $22,03 \%$ remaja laki-laki (Kussoy, dkk, 20013), Penelitian lain menunjukkan ada $17 \%$ remaja laki-laki yang obesitas dan 31\% remaja perempuan yang obesitas di kabupaten Bolaang Mongondouw Utara (Ratulangi, dkk, 2016). Penelitian juga menyebutkan bahwa remaja obesitassebesar 22,8 $\%$, lebih banyak terjadi pada remaja perempuan daripada remaja laki-laki (Hendra, dkk, 2016)

Tubuh yang mengalami ketidak seimbangan antara asupan energi dengan keluaran energi akan mengalami kelebihan energi yang kemudian disimpan dalam bentuk jaringan lemak (Ikatan Dokter Anak Indonesia, 2014). Demikian juga dengan kelebihan asupan karbohidrat, kelebihan asupan protein, dan kelebihan asupan lemak, dapat disimpan menjadi jaringan lemak. Simpanan menumpuk di tubuh menyebabkan terjadi obesitas. Pola makan yang merupakan pencetus terjadinya kegemukan dan obesitas adalah mengkonsumsi makanan porsi besar (melebihi dari kebutuhan), makanan tinggi energi, tinggi lemak, tinggi karbohidrat sederhana dan rendah serat. Sedangkan perilaku makan yang salah adalah tindakan memilih makanan berupa junk food, makanan dalam kemasan dan minuman ringan (soft drink).

Gizi lebih dan obesitas pada anak dan remaja ditegakkan berdasarkan anamnesis, pemeriksaan fisis, pemeriksaan antropometris, dan deteksi dini komorbiditas yang dibuktikan dengan pemeriksaan penunjang terkait (Sjarif dkk 2014). Hasil pemeriksaan ekokardiografi pada remaja menemukan semua remaja obesitas mengalami hipertropi ventrikal kanan (Larasaty dkk, 2011). Remaja obesitas juga memiliki laju denyut jantung yang tidak normal, hal ini diduga akibat adanya hiperaktivitas sistem saraf simpatis. Penelitian lain menyatakan bahwa obesitas berisiko menyebabkan diabetes mellitus, hipertensi, stroke, gagal nafas, nyeri sendi osteotritis, batu empedu, masalah psikososial, kanker, dan masalah kesehatan lainnya (Husnah, 2012).

Obesitaspada masa anak berisiko tinggi menjadi obesitas dimasa dewasa dan berpotensi mengalami penyakit metabolik dan penyakit degeneratif dikemudian hari. Profil lipid darah pada anak obesitas menyerupai profil lipid pada penyakit kardiovaskuler dan anak yang obesitas mempunyai risiko hipertensi lebih besar (Kemenkes, 2012). Remaja obesitas, berdasarkan hasil penelitian, diprediksiakan mendapatkan stigma yang berpotensi mempengaruhi perkembangan psikologis selama masa awal kehidupannya dan memiliki konsekuensi jangka panjang untuk kesehatan mental selama masa transisi sampai dewasa (Mustillo et al., 2013). Obesitas pada remaja laki-laki akan mengalami tekanan psikologis melalui label negative dari orang tua dan teman gadisnya. Obesitas pada remaja berdampak pada penurunan prestasi sekolah dan kemampuan kognitif (Martin et al, 2014). Penelitian ini bertujuan untuk membandingkan faktor yang berhubungan dengan remaja obesitas dengan remaja tidak obesitas pada beberapa variable perilaku sehat.

\section{SUBYEK DAN METODE}

Desain penelitian ini adalah observasional dengan pendekatan Cross Sectional. Penelitian dilakukan di sebuah SMA di wilayah Jakarta Utara, dimana kriteria inklusi sampel adalah siswa/i yang berada di kelas 10 dan 11 serta kondisi sehat, yang hadir dan bersedia diwawancara saat pengumpulan data, sedangkan kriteria eksklusi sampel adalah tidak meminum obat pelangsing. Variabel penelitian ini adalah status obesitas, kebiasaan makan fast food, kebiasaan jajan, jenis jajanan, lamanya menonton TV dan tidur siang. Data yang dikumpulkan berjenis data primer, dengan pengumpulan data obesitas dilakukan dengan mengumpulkan data berat badan dan 
tinggi badan, yang kemudian dimasukkan dalam perhitungan nilai indeks massa tubuh $(\mathrm{kg} / \mathrm{m} 2)$. Pengukuran berat badan dengan timbangan berat badan merek (satuan $\mathrm{kg}$ ), dan alat mikrotoise untuk tinggi badan. Pengumpulan data kebiasaan konsumsi fast food dan kebiasaan jajan dan tidur siang dengan cara wawancara menggunakan kuesioner. Analisis data dilakukan dengan analisis perbandingan proporsi.

\section{HASIL}

Responden dalam penelitian ini terdiri dari laki-laki $(57,5 \%)$ dan perempuan
(42,5\%). Rerata umur responden 16,8 tahun, dengan kisaran umur 15 tahun sampai 17 tahun. Perbedaan kebiasaan makan fast food, perilaku jajan di sekolah dan di rumah antara remaja obesitas dan remaja bukan obesitas dapat dilihat pada gambar 1 .

Remaja obesitas lebih banyak yang memiliki kebiasaan konsumsi Fast Food (90\%) daripada remaja bukan obesitas. Remaja obesitas juga lebih banyak yang memiliki kebiasaan jajan di sekolah $(98,3 \%)$, sedangkan remaja bukan obesitas lebih banyak memiliki kebiasaan jajan di rumah $(53,3 \%)$.

Gambar 1. Perbandingan Remaja Obesitas dengan Remaja Tidak Obesitas Berdasarkan Kebiasaan Konsumsi Fast Food, Kebiasaan Jajan di Sekolah, dan Kebiasaan Jajan di Rumah

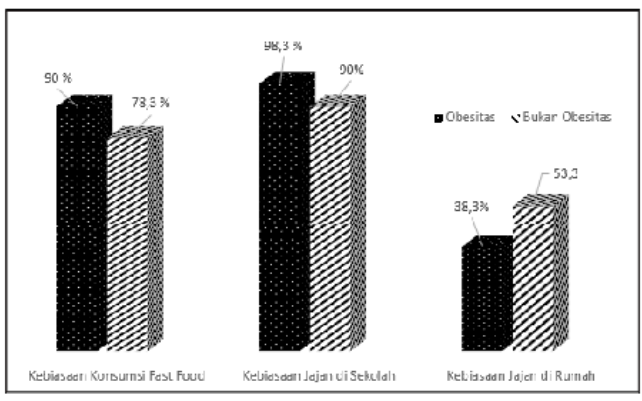

Tabel 1. Perbandingan Remaja Obesitas dengan Remaja Tidak Obesitas Berdasarkan Jenis Jajanan

\begin{tabular}{lcccc}
\hline Jenis Jajanan & \multicolumn{2}{c}{ Remaja Obesitas } & \multicolumn{2}{c}{ Remaja Tidak Obesitas } \\
\cline { 2 - 5 } & $\mathbf{n}$ & $\mathbf{\%}$ & $\mathbf{n}$ & $\mathbf{\%}$ \\
\hline Jenis jajanan paling sering dikonsumsi di sekolah & & & & \\
$\quad$ Makanan utama & 35 & 59,3 & 25 & 46,3 \\
Minuman & 13 & 22,0 & 10 & 18,5 \\
Snack & 9 & 15,3 & 15 & 27,8 \\
$\quad$ Lainnya & 2 & 3,4 & 4 & 7,4 \\
Jenis jajanan paling sering dikonsumsi dirumah & & & & \\
$\quad$ Makanan utama & 2 & 9,1 & 2 & 6,3 \\
Minuman & 8 & 36,4 & 9 & 28,1 \\
Snack & 11 & 50,0 & 21 & 65,6 \\
Lainnya & 1 & 4,5 & 0 & 0 \\
Lamanya menonton televisi per-hari & & & & \\
$\quad<2$ jam & 7 & 11,7 & 28 & 46,7 \\
2-4 jam & 24 & 40 & 23 & 38,3 \\
$\quad$ Lebih dari 4 jam & 29 & 48,3 & 9 & 15 \\
Kebiasaan tidur siang & & & & \\
Tidak Tidur siang & 43 & 71,7 & 52 & 86,7 \\
Tidur siang 1 jam & 9 & 15 & 1 & 1,7 \\
Tidur siang 1,5 jam & 1 & 1,7 & 3 & 5 \\
Tidur siang 2 jam & 7 & 11,7 & 3 & 5 \\
Tidur siang 3 jam & 0 & 0 & 1 & 1,7 \\
\hline
\end{tabular}


$176 \sim$ Retno Mardhiati, Arif Setiawan Perbandingan Perilaku Jajan, Konsumsi Makanan Cepat Saji serta Tidur...

Tabel 1. Menunjukkan paling banyak, remaja obesitas $(59,3 \%)$ dan remaja bukan obesitas (46,3\%) sama-sama memiliki kebiasaan jajan makanan utama atau lengkap di sekolah. Remaja Obesitas (50\%) dan remaja bukan obesitas $(65,6 \%)$ memiliki kebiasaan jajan snack ketika di rumah.

Hasil penelitian menunjukkan remaja obesitas $(48,3 \%)$ lebih banyak yang nonton televisi lebih dari 4 jam per-hari, sedangkan remaja yang bukan obesitas (46,7 \%) lebih banyak menonton televisi kurang dari 2 jam perhari. Hasil penelitian juga menunjukkan remaja obesitas lebih banyak yang tidur siang daripada remaja yang tidak obesitas. Remaja obesitas lebih banyak yang tidur siang selama 1 jam dan 2 jam.

\section{DISKUSI}

Hasil penelitian menunjukkan bahwa remaja obesitas lebih banyak yang memiliki kebiasaan konsumsi makanan cepat saji daripada remaja tidak obesitas. Beberapa penelitian menyatakan kebiasaan jajan pada remaja juga berpengaruh pada kejadian obesitas, dimana konsumsi makanan cepat saji, softdrink dan makanan berlemak menjadi faktor risiko untuk obesitas. Hal ini sejalan dengan penelitian lain dimana faktor yang berhubungan dengan obesitas antara lain ialah pola makan yang kurang asupan serat, sering mengkonsumsi makanan cepat saji dan kurang beraktivitas (Kurdanti, 2015; Sartika, 2011; Rumida, 2014; Hendra, 2016). Hendra dkk (2016) menyatakan faktor risiko yang berpengaruh terhadap obesitas pada remaja di Kota Bitung yang tertinggi adalah faktor pola makan yaitu sebesar 98\% sedangkan faktor riwayat keturunan sebesar $76 \%$, faktor pola hidup, aktivitas fisik dan lingkungan sebesar 24\% dan faktor lainnya seperti faktor psikis dalam hal ini stress atau kekecewaan yaitu sebesar $14 \%$. Penelitian ini tidak mengamati konsumsi serat namun hasil perbandingan proporsi diperoleh kebiasaan konsumsi makanan cepat saji lebih banyak dimiliki remaja obesitas. Makanan cepat saji pada umumnya memiliki kandungan lemak tinggi dan rendah serat.

Di Indonesia, kebiasaan konsumsi buah dan sayur pada remaja, masih rendah. Kemenkes (2015) menyatakan hanya $17,08 \%$ remaja laki-laki dan 14,69 \% remaja perempuan yang mengkonsumsi buah 3 kali sehari atau lebih. Remaja laki-laki yang mengkonsumsi sayur 3 kali atau lebih sehari ada 28,22 \% dan remaja perempuan ada $28,98 \%$. Konsumsi makanan cepat saji minimal 1 hari seminggu, ada $54 \%$ remaja laki-laki dan 56,17 \% remaja perempuan. Sebanyak $28,33 \%$ laki-laki dan $29,59 \%$ perempuan biasa 1 hari sekali dalam 7 hari sekali mengkonsumsi makanan siap saji. Sementara persentase pelajar yang mengkonsumsi makanan cepat saji setiap hari adalah sebesar $1,67 \%$ pada laki-laki dan 1,40\% pada perempuan. Beberapa penelitian juga mengungkapkan adanya kebiasaan konsumsi makanan dan pola makan yang cenderung tinggi energi dan lemak dimiliki remaja obesitas (Buanasita, 2015; Suryaputera, 2012); Mokolensang dkk, 2016)

Jenis jajanan di sekolah lebih banyak makanan utama karena sebagian besar remaja sarapan di sekolah dan makan siang juga di sekolah. Remaja di SMA jarang berperilaku membawa bekal ke sekolah, sebagian besar menggunakan jam istirahat untuk makan siang di kantin sekolah. Salmiah dkk (2015) menyatakan remaja obesitas laki-laki memiliki pengetahuan tentang pola menu seimbang lebih rendah daripada remaja obesitas perempuan. Remaja menyatakan sumber informasi terbanyak tentang pola menu seimbang diperoleh remaja dari internet $(38,9)$ daripada media cetak. Suryaputera dkk (2012) menyatakan remaja yang obesitas lebih banyak memiliki pengetahuan yang kurang.

Hasil penelitian menunjukkan bahwa remaja obesitas lebih banyak yang menonton televisi lebih dari 4 jam per-hari. Kemenkes (2012) menyatakan penyebab obesitas pada remaja antara lain, pola makan dan perilaku makan, kurangnya aktivitas fisik. Keterbatasan lapangan untuk bermain dan kurangnya fasilitas untuk beraktivitas fisik menyebabkan anak memilih untuk bermain di dalam rumah. Selain itu, kemajuan teknologi berupa alat elektronik seperti video games, playstation, televisi dan komputer menyebabkan anak malas untuk melakukan aktivitas fisik.

Hasil penelitian menunjukkan bahwa remaja obesitas lebih banyak yang tidur siang daripada remaja yang tidak obesitas. Hammersley et al. (2016) menyatakan 8 studi menemukan 
adanya hubungan obesitas dengan aktivitas fisik.. Penelitian yang berkaitan dengan waktu tidur juga menemukan ada kaitan antara obesitas pada remaja dengan pola tidur, salah satunya penelitian Hart et al. (2011) yang menyatakan sebuah studi epidemiologi dari 29 penelitian di 16 negara menunjukkan bahwa tidur pendek berisiko terjadi obesitas. Waktu tidur yang terlambat juga ditemukan sebagai faktor risiko obesitas. Hanya mekanismenya belum ditemukan.

Obesitas pada remaja dapat dicegahdengan beberapa intervensi. Sjarif dkk (2014) menyatakan pencegahan terjadinya gizi lebih dan obesitas terdiri dari 3 tahap, pencegahan primer dengan menerapkan pola makan dan aktivitas yang benar sejak bayi, pencegahan sekunder dengan mendeteksi early adiposity rebound, dan pencegahan tersier dengan mencegah terjadinya komorbiditas.Kemenkes (2012) pencegahan obesitas dilakukan dengan mempromosikan gaya hidup sehat meliputi pola dan perilaku makan serta aktivitas fisik kepada remaja, orang tua dan guru di sekolah. Promosi kesehatan dilakukan dari lingkungan keluarga, sekolah, masyarakat, dan fasilitas pelayanan kesehatan. Promosi kesehatan yang dilakukan di lingkungan sekolah, merupakan tempat yang baik untuk pendidikan kesehatan warga sekolah terutama siswa/i. Promosi kesehatan di lingkungan sekolah bertujuan terbentuknya perilaku makan sehat dalam waktu jangka lama, antara lain peningkatan kebiasaan konsumsi buah dan sayut, pengurangan makanan dan minuman yang manis, pengurangan makanan tinggi energid an lemak, pengurangan konsumsi junk food. Konsumsi buah dan sayur lebih dari 5 porsi per-hari, membiasakan sarapan dan membawa bekal makan siang ke sekolah, makan sesuai dengan waktunya.

Remaja obesitas juga butuh diintervensi. Intervensi pengobatan obesitas remaja dilakukan secara multikomponen yang menargetkan peningkatan aktifitas fisik dan diet sehat. Beberapa penelitian intervensi dilakukan untuk pengobatan obesitas pada remaja. Loveman et al. (2015) menyatakan intervensi pengobatan obesitas pada remaja, lebih efektif jika diberikan edukasi pada orang tua remaja. Intervensi pengobatan obesitas remaja dilakukan secara multikomponen yang menargetkan peningkatan aktifitas fisik dan diet sehat. Anto dkk (2017) menyatakan pengaruh pemberian konseling pada remaja obesitas, dapat memotivasi remaja untuk menurunkan berat badan dan merubah perilaku, sehingga terbentuk pola makan yang baik, asupan gizi yang cukup, dan aktivitas fisik yang aktif. Sartika (2011) menyatakan perlu dilakukan upaya pencegahan dan penanggulangan faktor risiko obesitas dengan menanamkan pendidikan kesehatan pada anak sejak usia dini, melalui peningkatan KIE (komunikasi, informasi dan edukasi), seperti gerakan anti rokok, gerakan cinta serat (sayur dan buah) serta membudayakan aktivitas fisik. Kemenkes (2012) konseling gizi diberikan setelah ada diagnosa gizi, perhitungan kebutuhan gizi, penentuan jenis diet, syarat diet, penyusunan menu, kebiasaan makan yang sehat, jenis bahan makanan yang biasa dikonsumsi, frekuensi makanan sehari, porsi makanan, asupan makan sehari, pantangan terhadap makanan.

Beberapa intervensi sudah dilakukan untuk remaja obesitas namun keberhasilan belum sesuai harapan. Salam (2010) menyatakan obesitas merupakan hasil dari proses yang berjalan menahun, sehingga penanganannya tidak akan efektif bila hanya dalam waktu singkat. Ada beberapa cara penanggulangan yang bisa kita lakukan seperti: melakukan intervensi gizi, melakukan aktifitas fisik, farmakoterapi dan intervensi bedah. Penerapan pola makan seimbang dan peningkatan aktivitas fisik pada anak sekolah bukanlah hal yang mudah. Diperlukan dukungan dariorang tua, guru, tenaga kesehatan, dan pihak lainnya. Berkaitan dengan hal itu maka upaya penanggulangan ini harus menjadi komitmen nasional yang harus dilakukan secara sistimatis dan terpadu serta berkelanjutan.

\section{KESIMPULAN}

Ada perbedaan proporsi, dimana remaja obesitas lebih banyak yang memiliki kebiasaan konsumsi makanan cepat saji. Remaja obesitas juga lebih banyak yang memiliki kebiasaan jajan di sekolah daripada di rumah. Remaja obesitas dan bukan obesitas memiliki kebiasaan jajan makanan utama atau lengkap di sekolah. Remaja Obesitasdan remaja bukan obesitas memiliki kebiasaan jajan snack ketika di rumah. Remaja obesitas lebih banyak yang nonton televisi lebih dari 4 jam per-hari. Obesitas pada remaja memerlukan perhatian yang serius dan 
penanganan yang tepat dengan melibatkan peran orang orang dekat dalam lingkungan hidupnya seperti orang tua dan guru di sekolah.Upaya edukasi dalam bentuk penyuluhan dan konseling pada remaja obesitas secara kontinyu, diharapkan dapat merubah perilaku makan dan gaya hidup remaja obesitas mejadi lebih sehat.

\section{DAFTAR PUSTAKA}

Anto, Sudarman S, Yetti RE, Manggabarani S. 2017. Pengaruh Konseling Memodifikasi Gaya Hidup Terhadap Pencegahan Obesitas Pada Remaja. PROMOTIF, Volume 7, Nomor 2, hlm : 99-106

Antwi F, Fazylova N, Garcon MC, Lopez L, Rubiano R, Slyer JT. 2012. The effectiveness of web-based programs on the reduction of childhood obesity in school-aged children: A systematic review. JBI Libr Syst Rev. 2012;10(42 Suppl):1-14.

Buanasita A, Andriyanto, Sulistyowati I. 2015. Perbedaan Tingkat Konsumsi Energi, Lemak, Cairan, dan Status Hidrasi Mahasiswa Obesitas dan Non Obesitas. Indonesian Journal of Human Nutrition, Vol.2 No.1, hlm : 11 - 22

Childhood, E., Tasked, O., Who, T., Growth, C., \& Controlling, S. (2018). Quick links, 26-28.

de Onis M, Blössner M, Borghi E. 2010. Global prevalence and trends of overweight and obesity among preschool children. Am J Clin Nutr. 92:1257-64.

Hart CN, Cairns A, Jelalian E. 2011. Sleep and Obesity in Children and Adolescents. Pediatr Clin North Am. ; 58(3): 715-733.

Hammersley ML, Jones RA, Okely AD. 2016. ParentFocused Childhood and Adolescent Overweight and Obesity eHealth Interventions: A Systematic Review and Meta-Analysis. J Med Internet Res, 18 (7): e203

Hendra C, Manampiring AE, Budiarso F. 2016. FaktorFaktor Risiko Terhadap Obesitas Pada Remaja Di Kota Bitung. Jurnal e-Biomedik (eBm), Vol 4, No 1

Husnah. 2012. Tatalaksana Obesitas. Jurnal Kedokteran Syiah Kuala Vol 12, No 2, hlm : 99-104

Kemenkes. 2012. Pedoman Pencegahan dan Penanggulangan Kegemukan dan Obesitaspada Anak Sekolah. Jakarta : Kementerian Kesehatan RI

Kemenkes. 2015. Perilaku Berisiko Kesehatan Pada Pelajar SMP Dan SMA Di Indonesia. Jakarta : Kementerian Kesehatan

Kurdanti W, Suryani I, Syamsiatun NH, Siwi LP, Adityanti MM, Mustikaningsih D, Sholihah KI. 2015. Faktor-faktor yang mempengaruhi kejadian obesitas pada remaja Risk factors for obesity in adolescent. Jurnal Gizi Klinik Indonesia, Vol. 11, No. 4, hlm : 179-190
Kussoy K, Fatimawali, Kepel B. 2013. Prevalensi Obesitas Pada Remaja Di Kabupaten Minahasa. Jurnal e-Biomedik (eBM), Vol 1, No 2, hlm : 981985

Larasaty S, Djais J, Rahayuningsih SE. 2011. Hubungan Obesitas Remaja dengan Hipertrofi Ventrikel Kanan berdasarkan Pemeriksaan Elektrokardiografi. Sari Pediatri, Vol. 12, No. 6, hlm : 391-396

Loveman E, Al-Khudairy L, Johnson RE, Robertson W, Colquitt JL, Mead EL, Ells LJ, Metzendorf MI, Rees K. 2015. Parent-only interventions for childhood overweight or obesity in children aged 5 to 11 years. Cochrane Database Syst Rev. 21;(12):CD012008.

Martin A, Saunders DH, Shenkin SD, Sproule J. 2014. Lifestyle intervention for improving school achievement in overweight or obese children and adolescents. Cochrane Database Syst Rev. 2014 Mar 14;(3):CD009728

Mokolensang OG, Manampiring AE, Fatimawati. 2016. Hubungan Pola Makan Dan Obesitas Pada Remaja Di Kota Bitung. Jurnal e-Biomedik (eBm), Vol 4, No 1

Mustillo SA, Budd K, Hendrix K. 2013. Obesity, Labeling, and Psychological Distress in LateChildhood and Adolescent Black and White Girls, The Distal Effects of Stigma. Social Psychology Quarterly, Volume: 76 issue: 3, page(s): 268-289

Ratulangi AJ, Bodhi W, Manampiring A. 2016. Hubungan Tekanan Darah Dengan Obesitas Pada Remaja Obes Dan Non-Obes Di Kabupaten Bolaang Mongondouw Utara. Jurnal Kedokteran Klinik (JKK), Volume 1, No 1, hlm : 55-63

Rumida. 2014. Pengaruh Perilaku Makan Dan Aktivitas Fisik Terhadap Kejadian Obesitas Pada Pelajar Di Smu Methodist Medan. Wahana Inovasi Vol 3 No.1, hlm : 6-13

Salmiah, Rochimiwati SN, Asbar R, Amir N. 2015. Remaja Obesitas Tentang Pengetahuan Pola Menu Seimbang Di Smpn 30 Makassar. Media Gizi Pangan, Vol. XIX, Edisi 1, hlm : 55-59

Salam A. 2010. Faktor Risiko Kejadian Obesitas Pada Remaja. Jurnal MKMI Vol 6 No.3, hlm 185-190

Sartika RAD. 2011. Faktor Risiko Obesitas pada Anak 5-15 Tahun di Indonesia. Makara, Kesehatan, Vol. 15 , No. 1 , hlm : $37-43$

Sjarif DR,Gultom CL, Hendarto A, Lestari ED, Sidiartha IGL, Mexitalia M. 2014. Diagnosis, Tata Laksana dan Pencegahan Obesitas pada Anak dan Remaja. Jakarta : Ikatan Dokter Anak Indonesia

Suryaputra K, Nadhiroh SR. 2012. Perbedaan Pola Makan Dan Aktivitas Fisik Antara Remaja Obesitas Dengan Non Obesitas. Makara, Kesehatan, Vol. 16, No. $1: 45-50$ 